\title{
The Results of Social and Economic Modernization of the Central Asian National Outskirts of the Russian Empire as a Resource for Forming Ethnic Identities
}

\author{
Yuliya Lysenko \\ Department of History, Altai State University, 61, Lenina Ave., Barnaul, Altai Krai, Russia \\ Email: iulua_199674@mail.ru \\ Inna Anisimova \\ Department of History, Altai State University, 61, Lenina Ave., Barnaul, Altai Krai, Russia \\ iva0410@mail.ru \\ Elena Tarasova \\ Department of History, Altai State University, 61, Lenina Ave., Barnaul, Altai Krai, Russia \\ tarasova_e@rambler.ru \\ Marina Lysenko \\ Department of History, Altai State University, 61, Lenina Ave., Barnaul, Altai Krai, Russia \\ rina_flamme@mail.ru
}

\section{Doi:10.5901/mjss.2015.v6n6s4p119}

Abstract

\begin{abstract}
The article considers the process of economic modernization of the Central Asian national outskirts of the Russian Empire (late 19th - early 20th centuries) as a resource for forming ethnic identities. "Social and religious identities" based on class, religion, economic and cultural, regional and local, kin and clan division were characteristic of this ethno-region before the given period of time. The ethno-confessional component identified as Islamic was the top component in the structure of ethnic identity of the region's population. The way of economic modernization proposed by the Russian Empire significantly changed the economic structure of the traditional societies of the Central Asian region, expanded the industrial and agricultural production, and boosted urban development. Whereas this process objectively expedited the destruction of traditional social structures and relations, created conditions for growing mobility of the population, the development of national schools and mass media, thus forming ethnic self-consciousness and ethnic identity.
\end{abstract}

Keywords: Russian Empire, Central Asian national outskirts, modernization, ethnicity, identity, the Kazakhs, the Uzbeks, the Tajiks.

\section{Introduction}

Historical literature provides reasonable details of the process of economic development of the Central Asian national outskirts of the Russian Empire. Evaluating its common tendencies and analyzing the economic interests of the government, a minimum two points of view can be considered as dominant. According to the first viewpoint dominant in Russian historiography of the imperial period and in the research works by Soviet authors of the 1960-1980s the Russian economic policy pursued in the given ethno-region was entirely progressive and had positive consequences. All this resulted in the development of market relations in traditional economies, their integration into all-Russian and world markets, growth of social mobility, and urban development etc (Bekmahanov, 1954).

Some research workers and political writers of the $19^{\text {th }}$ - early $20^{\text {th }}$ centuries, Soviet social scientists of the 1920 1930 s as well as modern scientists of those countries that emerged in the post-Soviet Central Asian territory supported the second point of view. They considered the Russian economic policy concerning non-Russian nations in the light of the process of colonization. Therefore its results got a negative evaluation. This policy was marked by the "mercenary purposes" of the Russian autocracy aiming to increase the exploitation of the natural and demographic resources of the national outskirts, extend the Russian investment outlet and seek for "new markets for these goods". The Russian policy concerning traditional societies, i.e. indigenous peoples of Russian Asia, was strongly criticized. The aim of the Imperial 
ruling circles to integrate these ethno-economies into the all-Russian system in the post-reform period was accompanied by their collapse, the crisis of traditional environmental support systems, heavy social costs, and the strengthening of colonial exploitation etc (Sadvokasova, 2004).

We do not aim to reconcile the two points of view, however, it should be pointed out that there is a significant component lacking in the discourse on the consequences of the economic policy of the Russian Empire in the Central Asian outskirts. The point at issue is that the peoples of the region were not in fact involved in the process of ethnic consolidation either during the late Middle Ages or the present time. By the time the land was conquered by the Russian Empire (mid. 19th century) "social and religious identities" had been formed here. They were based on divisions of class ("hoi polloi and aristoi"), religion (the Sunnis, the Shias, the Ismailis belonging to different Sufi orders and brotherhoods), economic and cultural (nomadic, semi-nomadic, sedentary, mountain), regional and local (population of Bukhara, Samarkand, Tashkent, Kokand, Andijan etc) kin and clan ( the Mang'its, the Kipchaks, the Naimans, the Kungrats, the Yuz, the Tekins, the Yomuts etc) (Abashin, 2007: 260).

As a result the structure of ethnic self-consciousness of the sedentary population of Central Asia represented a complex multilevel hierarchy, with the upper level identified by the affiliation to Islam. This was the reason why V. Bartold and other ethnographers of the late $19^{\text {th }}$ - early $20^{\text {th }}$ centuries noted the fact that "a sedentary resident of Central Asia first of all considers himself as a Muslim, and then a resident of a certain city or territory; the thought of his affiliation to a certain nation does not bother him at all" (Bartold, 1964: 528-529). Identifying yourself as a "Tajik", "Uzbek" or a "Uyghur" was not so important for the population of the region. The most important thing was to identify yourself as a "Bukharan", "Khotan", "Fergan", "Kashgar". All these self-designations reflected an affiliation to ethnic local historical-cultural communities, groups of sedentary Turkistanians, and also included religious affiliation.

Clan identity was dominant in the ethnic consciousness of the region's nomads - the Kazakhs, the Turkmen, the Kyrgyz. To cite an example, it is known that the Kazakh population was divided into three zhuzhes: Junior, Middle and Elder. All parts of the zhuzh structure had complex genealogical traditions connecting their affiliation to one real or legendary ancestor. Islam appeared to a far lesser extent an ethno-forming and ethno-identifying element among the nomadic peoples of Central Asia.

Some research workers believe that a number of objective factors and conditions are necessary to start formation of a national identity; among them are historical foundation, the experience of a state form of government and government control, and the existence of national-hued conflicts of interest, whereas the process of modernization (industrialization) is an important condition. As used here it is arguable that the economic policy of the Russian Empire in the Central Asian national outskirts was not analyzed in historical literature as a resource of forming ethnic identities. This article suggests reconsidering the issue.

\section{Material and Methods}

M. Khrokh's concept of stage formation of nationalism, national liberation movement and nations is a methodological basis of the research. Within this concept there should be a number of objective factors to develop the ideology of nationalism within any ethnic group. Modernization was one of the factors marked by M. Khrokh, however, modernization itself cannot be considered as a key factor of the emergence of "nationalism". The consequences of modernization causing the rise of social mobility, improvement of social communication and school systems are the most important factors for the growth of ethnic identity. Whereas, the intensity of social communication is determined by a few factors: migration, urbanization, availability of rail and road communications, mass media development (Anderson, Bauer, Khrokh, 2002). It is in this context that the article will further analyze the process of social and economic modernization carried out by the Russian Empire in the Central Asian national outskirts at the turn of the $20^{\text {th }}$ century.

\section{Discussion}

Traditional social-economic relations, strong patriarchal structure and undeveloped forms of human activities were dominant in the territory of Central Asia before it came under the influence of the Russian interests. Living in a specific environment (steppe and semi-desert areas), the nomadic population of the region raised cattle as their primary occupation. Extensive agriculture using primitive agricultural tools was dominant in oasis areas. On the whole the economic life of the Central Asian population was fairly isolated and insulated, orientated to a home market, their own production and consumption. The social standards and laws of a pre-industrial society excluded the opportunity for developing social mobility.

The existent situation can be explained by the following factors: huge isolated steppe areas located on the 
periphery, strongly continental climate and the lack of access to seas and oceans. Therefore the population of the region had no opportunity for contact with European civilization, or to adopt its achievements in science and technology. Another unfavorable factor was that the autocratic regimes characteristic of the political systems of the region's countries, shaped their policy within Islam thus preventing the development of a market economy (Leizerovich, 2001: 163).

The completion of the accession of the territories of the Elder zhuzh, the Kokand khanate conquest, with the khanate of Khiva and the emirate of Bukhara being included in the sphere of Russian interests through the system of a protectorate placed the question of the region's integration into the all-Imperial social and economic zone on the agenda. The realization of this strategic task took place at the time of the beginning of the bourgeois reformation in Russia, which was accompanied by the formation of a single all-Russian market, new social groups - the middle class and the working class, regional specialization, increase of social mobility of the Empire's population. The geopolitical context of the territorial expansion of Russia in Asia predominant in the first half of the $19^{\text {th }}$ century gave way to economic imperative (Lysenko, 2013: 176-184).

In the post-reform period mining and processing industries were the most developed industries in the two administrative-territorial entities, Stepnoy and Turkistan Governorate Generals, which were founded in the territory of Central Asia. Polymetallic ore was mined in the east, in the area of Rudny Altai, hard-coal deposits were developed in Central Kazakhstan, oil industry was developed in the territory of Caspiy and the Fergana valley. The processing industry was orientated to the local agricultural raw materials. Tallow rendering works, grain mill production, soap manufacture, oilseed processing industry and tanneries were developing all over. Salt extraction and construction materials production were also forming as independent industries.

The south of the Stepnoy krai and Turkestan specialized in cotton growing and processing. The cotton industry became the key industry in this area. Russia had to solve the problem of dependence on the supplies of high quality American cotton. By 1917 there had been 1198 manufactures in Turkestan, the emirate of Bukhara, the khanate of Khiva and Amu-Daryinsk district, with $43 \%$ cotton processing production. At the turn of the $20^{\text {th }}$ century the export turnover of cotton fiber dramatically increased from 13.9 million $\mathrm{kg}$ in 1888 to 219.2 million $\mathrm{kg}$ in 1913 (Rashin, 1958).

The development of a communications system was a great breakthrough for fast integration of the Stepnoy krai and Turkestan into the imperial economic zone. The first Orenburg railway connecting the Turgai oblast and Orenburg with Central Russia was built in the region in the 1870-1880s. The construction of the railway line "Pokrovskaya sloboda - Uralsk" was under way in 1891-1893, and the railway line "Urbakh - Astrakhan" - in 1897. The Zacaspian railroad came into operation in this period of time, and the Trans-Siberian Railroad and Orenburg-Tashkent railroad - in the early $20^{\text {th }}$. A net of railways facilitated the dissolution of the region's economic isolation and created extra jobs.

The modernization process was accompanied by urbanization. By 1914 there were 26 municipalities in the Stepnoy krai, 7 of them were founded in the 18th century, and 24 were incorporated in the 19th century. Most of the towns used to be small settlements in the post-reform period, with overall urban population making up 231,951 by the year of 1897. The cities of Turkestan - Tashkent, Kokand, Andijan, Samarkand, Ashkhabad - became large centers of economic life with private factories, major financial and educational institutions.

On the whole the modernization process which began in the second half of the $19^{\text {th }}$ century significantly changed the social-economic structure of the Stepnoy krai and Turkestan. Mining and processing industries as well as the construction of railways were flagships of the reformation. One could observe an active urban life, the development of a credit and banking system, and a trade and labor market. The output of industrial production and agricultural production increased, including large-scale urbanization as the consequences of modernization. All this undoubtedly predetermined the growth of social mobility of the region's population.

The growth of social mobility of the indigenous peoples of the Stepnoy krai and the Turkestan krai in that period of time was characterized by their participation in the process of modernization, forming their own niche in new businesses and the use of hired labor. At the turn of the $20^{\text {th }}$ century the national middle class was going through the period of formation and original accumulation of capital. They made financial investments mainly into the processing industry, and in the Turkestan krai - into the cotton industry; the middle class merchants got wider representation. (Anisimova, et al., 2014).

Indigenous ethnic groups took an active part in the formation of the regional labor market. Moreover labor migration in the second half of the $19^{\text {th }}$ century was legislated. The rules of "moving to cities" for broke cattle-farmers and agricultural workers of the territory were determined by "The Provisional Statute" on administering the Orenburg and West-Siberian Governorate-Generals of 1868 and the Turkestan Governorate-General of 1867. In the early 20th century the proportion of the Kazakhs migrating to cities for earnings made up e.g. $4.6 \%$ in the Kokchetav uyezd (a secondary level of administrative division) and up to $7.0 \%$ - in the Atbassarsk uyezd. From this data it can be argued that the direction of farmers going to work in other industries and places had been formed as a separate social category of the 


\section{Kazakh society by the early 20th century.}

On the whole, according to the first all-Russian census of 1897 the total number of hourly and salaried workers employed in the industry and transport, communications and trade of the Stepnoy krai made up approx. 18,000 people. It was estimated that this index had risen to 75,000 people by the beginning of World War I. In the Turkestan krai this index was approx. 35,000 people. (Dilmukhamedov, 1963)

Local ethnic groups were in a majority among factory workers. Thus in 1913 the Russians made up $22 \%$ of 20,925 factory workers in the Turkestan krai, the Uzbeks $-60 \%$, the Kazakhs $-4.5 \%$, the Tajiks $-5.5 \%$, the Uyghurs $-5.5 \%$, and other ethnic groups $-5.1 \%$. Moreover most workers who represented local ethnic groups were involved in the key sectors of production, with the Uzbeks making up $69 \%$, the Russians $-20.2 \%$, the Kazakhs $-5.4 \%$, the Tajiks $-0.4 \%$, the Uyghurs and others $-1.3 \%$. Among menial workers the Uzbeks comprised $50.5 \%$, the Tajiks $-24.4 \%$, the Uyghurs and the Dunghans $-21 \%$, the Russians $-13.2 \%$ and the Kazakhs $-1.7 \%$. There were few qualified workers among the representatives of the indigenous population who were involved in the production and repair of engines; the Russians comprising $79.9 \%$ of the workers made up the majority.

Among the workers occupied in railway transport, the Russians who had a higher level of professional training, made up the majority. In 1908 Russian full-time workers made up $92.8 \%$ of the workers in the Orenburg-Tashkent railroad, with non-Russian workers making up only $7.9 \%$ ( among them: the Polish $-3.11 \%$, the Kazakhs $-2.2 \%$, the Germans $-0.72 \%$ etc). The Kazakhs were employed as day laborers for seasonal work for the maintenance of the railroads. The proportion of day laborers in railway transportation representing the Kazakh ethnic groups made up approx. $20 \%$ or $5,000-6,000$ people. The local industrial proletariat comprised $77 \%$ of the total workers of Turkestan in the early $20^{\text {th }}$ century ( Revolution of 1905-1907 in Central Asia and Kazakhstan, 1985: 5).

The analysis of the sphere of the ethnic population employment of the Stepnoy krai and Turkestan allows us to speak about the formation of a social group of minor officials in the administrative-territorial system of government. The policy of co-opting the representatives of ethnic elites for management positions resulted from the growth of the territory of the country with vast regions making up parts of it but with a "development model" different from that in the center. This heterogeneity of territories, with most of them being far from the major political-administrative centers, required the strengthening of centralism and autocratic tendencies of the power, and the growth and empowerment of bureaucracy. Due to the lack of Russian government officials and a language barrier in some regions the solution was to involve local ethnic elites in administering local administrative-territorial units. Another reason for attracting the representatives of indigenous ethnic groups to civil service was to gain their support and loyalty in order to avoid centrifugal tendencies and regionalism. The formation of an ethnic management stratum as in many other ethno-regions of the Russian Empire was possible due to the development of secular school systems with further education obtained in the higher educational institutions of the Russian Empire.

Thus the way of modernization which was proposed to the Central Asian traditional societies by the Russian Empire objectively facilitated the destruction of traditional social structures and relations, and created conditions for the growth of the population mobility and therefore the formation of an ethno-consciousness and ethno-identification.

At the same time the industrialization policy of the Central Asian outskirts pursued by the government was generally in accordance with the traditional time-tested forms of external influence on backward economies. This meant that underdeveloped regions were connected with transport and trade systems of more developed regions. The main objective was to guarantee an uninterrupted exchange of traditional goods produced in underdeveloped regions for the industrial production of the central regions. In this case an undeveloped household system integrated into relatively advanced market and production infrastructure.

It should be noted that Russian policy in the Central Asian national outskirts was mainly of geostrategic character and was determined by the need for military security and state stability. That made the Russian colonial model different from the European one: the latter was characterized by its aspiration to capture "new market channels and sources of cheap raw materials for domestic industry" especially in the period of commercial and industrial colonialism; as to the former model, the economic imperative had never been determinant for its territorial annexation (Shaidurov, 2014).

This thesis confirms the economic specificity of the metropolitan Russian Empire. It is known that this capitalist model, originating in the depths of serfdom, took highly original forms. This model was characterized by a weak Russian middle class, the incomplete process of its structural and class formation, and the dominance of state capitalism in the industrial sector which was then aimed at primary production. In the existent situation, Russian industrialists did not have enough financial resources for active investment into the regional economy. It is significant that such large industrial companies of the second half of the $19^{\text {th }}$ century as AO Spasskiye Copper ores, AO Atbassarskiye Copper Spears and the gold-mining Russian-Asian Corporation, were set up in the Stepnoy krai using only foreign investments (Fridman, 1960). 
These facts allow us to speak about the weak influence of modernization processes on traditional societies and the incomplete process of industrialization in the Central Asian region of the Russian Empire. The number of companies and the production output in the Stepnoy krai were growing slowly compared to the industrial growth in the central provinces of Russia. In 1913 there were only $0.7 \%$ of local industrial enterprises in the region, with only $0.2 \%$ employed out of the total number of workers. The proportion of industrial production of the Stepnoy krai for all-Russian production made up no more than 0.3\% shortly before World War I. (Zhirenchin, 1996: 148-153).

According to the first all-Russian census of 1897 the employment structure of the Kazakh population, for example, was as follows: out of the total number of Kazakhs, $72 \%$ were involved in animal breeding, $24 \%$ in farming, $1.46 \%$ in private service, $0.52 \%$ in trade. The ethnic composition of city dwellers was mainly determined by the agricultural policy of the Russian Empire as well as the associated mass migration of East Slavic peoples to the region. Therefore the Russian population dominated in the towns of the Stepnoy krai. According to the 1897 census the proportion of Russians among the city dwellers of the Uralsk oblast (province) comprised $82.8 \%$, the Turgai oblast $-76.2 \%$, the Akmolinsk oblast -56.4 $\%$, the Semipalatinsk oblast - 54\%; with total $66.7 \%$ of Russians in all these territories. The Kazakhs made up $16 \%$ out of all city dwellers living in the four territories. The composition of the indigenous population of the Turkestan krai was more rural: in the census of 1897 only 576,000 people or $11.6 \%$ out of $4,987,000$ lived in cities or towns. In the early $20^{\text {th }}$ century there was a small increase to $14.4 \%$ in the number of urban population.

\section{Conclusion}

Therefore the end of the Central Asian region's conquest by the Russian Empire in the 1860 - 1870s placed the question of the region's integration into the all-Imperial social and economic zone on the agenda. At the beginning of the bourgeois reformation in metropolitan Russia this ethno-region, experiencing the pre-industrial stage of social and economic development, was objectively involved in the process of modernization. It was accompanied by the destruction of traditional economies, potestary-clan and clan-marital relations, the formation of market and infrastructure, the growth of social mobility of the indigenous population, and the appearance of a national middle class, bureaucracy and regular labor force. All this suggests that the economic integration of the Central Asian population into an all-imperial zone created conditions for intensifying ethnic consolidation and forming ethnic identities.

However, on account of a wide range of exogenous and endogenous factors (weak economy of urban Russia, lack of upper middle class, Anglo-Russian rivalry in the Middle East etc), the process of modernization in Central Asia was of specific character, and it had not been completed by the beginning of World War I. This resulted in a primary production economy for the region, the dominance of foreign investments, the retention of traditional social forms and ties, and in weak processes of urbanization. Thus it can be argued that after acquiring the modernization plan, proposed by the Russian Empire, traditional societies of the Central Asian national outskirts gained certain conditions for social mobility, which was accompanied by the growth of ethnic self-consciousness. However, the above mentioned factors gave a slight impetus to these given tendencies. Therefore modernization, in this respect, was not considered as a dominant factor of the growth of the region's population ethnic identity, though it should be considered in conjunction with other factors.

\section{Acknowledgments}

The article is published with the financial support of the Russian Humanitarian Science Foundation, project № 15-3112023 "Revolutions of 1917 in Russia and "a nationalities question" (case study Central Asian national outskirts)"

\section{References}

Abashin, S., Arapov, D. (2007) Central Asia as a part of the Russian Empire, Moscow.

Anderson, B., Bauer, O., Khrokh, M. (2002) Nations and nationalism, Moscow: Praksis.

Bartold, V. (1964) Sartre. Essays, Vol. 2. P. 2., Moscow.

Bekmahanov, E. (1954) Kazakhstan in $20-40$ s of $20^{\text {th }}$ century, Moscow.

Dilmukhamedov, E., Malikov, F. (1963) Essays on the history of working class of pre-revolutionary Kazakhstan, Alma-Ata.

Fridman, Ts. (1960) Foreign capital in pre-revolutionary Kazakhstan, Alma-Ata.

Leizerovich, E. (2001) Social and economic results of the Russian colonization of Turkestan, Tel-Aviv.

Lysenko, Yu. (2013) On taxation policy of the Russian Empire towards Kazakh society, Barnaul: Bulletin of Altai State University, № 4/2.

Lysenko, Yu., Anisimova, I. et al.(2014) Traditional Kazakh society in the national policy of the Russian Empire: conceptual framework and realization mechanisms (19th - early $20^{\text {th }}$ centuries), Barnaul.

Rashin, A. (1958) Working class formation in Russia, Moscow. 
Revolutions of 1905 - 1907 in Central Asia and Kazakhstan, Tashkent (1985).

Sadvokasova, Z. (2004) Spiritual expansion of tsarism in Kazakhstan in tht19th - early $20^{\text {th }}$ centuries, Almaty.

Shaidurov, V. (2014) Jews and their social status in the society of Siberia in XIX century, Bylye Gody, Vol. 32 (2). pp.: 239-244.

Zhirenchin, K. (1996) Political development of Kazakhstan in the $19^{\text {th }}$ - early $20^{\text {th }}$ centuries, Almaty. 